\title{
Financial Systems in the Digital Age: Perspectives from Europe and Japan
}

\author{
Markus Heckel and Franz Waldenberger
}

\section{Motivation and Background}

Despite the global nature of finance, the institutions and business of finance have until today retained national features that are clearly discernible. These are so distinct and important that financial systems are in fact often considered a key element in the characterization of national systems of capitalism (Dore, 2000; Hall \& Soskice, 2001). We should therefore expect that the digital transformation (DX) of finance, its speed, scope and outcome should also be strongly influenced by national contexts. This proposition provided the main motivation for publishing this edited volume. There are numerous publications about how digitalization is transforming, if not disrupting, the financial industry. However, many publications either imply a world void of institutions or presuppose that DX is naturally a global and therefore uniform phenomenon (see for example Hines, 2021; Tapscott \& Tapscott, 2016; McMillan, 2014). We think this leaves out at least half of the story. To fully understand the actual implications of DX, one must look at national cases.

We started our project on the future of finance in the digital age in 2019 by setting up a study group of experts from Japanese academia, research institutions, and industry. It was planned that the group would produce position papers on issues related to DX and finance, and that these papers would be presented and discussed at a joint workshop with experts from the Deutsche Bundesbank and the European Central Bank in Frankfurt in 2020. The idea was to identify similarities and differences in the discourses about DX with regard to finance and the transformation apparent in Japan and the euro zone. The choice of countries was for the most part due to the fact, that the editors do research on Japan at an institute in Tokyo funded by the German government. That said, it perfectly served our motivation sketched above because

M. Heckel $(\varangle) \cdot$ F. Waldenberger

German Institute for Japanese Studies, Tokyo, Japan

e-mail: heckel@dijtokyo.org 
Japan and the euro zone, while constituting two of the four largest economies in the world, are not considered frontrunners when it comes to DX and related financial innovations. Their national discourses and experiences tend to be underrepresented in the international literature on DX and finance, which is dominated by accounts from the US and China.

Unfortunately, due to the COVID-19 pandemic, our idea of a joint workshop had to be given up. Instead, we decided to disseminate the findings of our study group in an edited volume and to include the euro zone perspective by inviting contributions from European experts, both scholars and practitioners. Altogether, we solicited eight chapters, five from Japan and three from Europe. The topics cover digital currencies, payment systems, banking, and trading in financial markets. Rather than developing abstract scenarios, they discuss specific cases within their respective contexts. The special feature and value the contributions derive from the fact that all authors have a profound and long professional background in the field of finance as academics, policymakers, or regulators. ${ }^{1}$ Nobuyuki Kinoshita acted as executive director of the Bank of Japan from 2010 to 2014. He now serves as president and CEO of the Tokyo Financial Exchange. Kiyotaka Sasaki spent a long career at the Ministry of Finance and the Financial Services Agency (FSA) Japan and is now visiting professor at Hitotsubashi University. Hiromi Yamaoka acts as the chairperson of the Digital Currency Forum. He previously worked for the Bank of Japan, the Bank for International Settlements, and the International Monetary Fund. Ulrich Bindseil served 7 years as the director, General Market Operations of the European Central Bank before he took up his current position as the director general of Market Infrastructure and Payment Systems. Alexander Bechtel is head of Digital Asset and Currency Strategy at the Corporate Bank of Deutsche Bank and worked as an external consultant to the European Central Bank. Agata Ferreira is a member of the EU Blockchain Observatory and Forum as well as the Advisory Council of Blockchain for Europe. She is also an assistant professor at Warsaw University of Technology. Jonas Gross is a project manager at the Frankfurt School Blockchain Center, chairperson of the Digital Euro Association, and member of the expert panel of the European Blockchain Observatory and Forum. Philipp Sandner is head of the Frankfurt School Blockchain Center and a member of the Fintech Council (FinTechRat) of the German Federal Ministry of Finance. Yuri Okina is chairperson of The Japan Research Institute. She advises the Japanese government as a member of the Financial System Council (Financial Services Agency) and the Industrial Policy Council (Ministry of Economy, Trade and Industry). Anna Omarini is professor of Banking and Fintech at the Department of Finance of Bocconi University and serves as an independent board member at Italian banks and other financial institutions. Takahide Kiuchi is executive economist at Nomura Research Institute. From 2012 to 2017, he was a member of the Policy Board of the Bank of Japan.

\footnotetext{
${ }^{1}$ More information about the authors can be found in the list of contributors.
} 


\section{Financial Systems: Functions, Resources, and Design}

In terms of value creation, financial systems fulfill subordinate or indirect functions. Money and payment infrastructures support the complex system of economic exchange on which the division of labor depends. Financial intermediation and capital markets provide for the financing of investment and liquidity and the diversification of risks associated with entrepreneurial activity. Consumer finance reduces the budgetary constraints of private households, granting them more purchasing options. Similarly, governments rely on public finance when balancing revenues and expenditures related to the provision of public services. Last but not least, financial instruments help to insure against various kinds of income risks faced by individuals and organizations.

In addition, financial systems perform important pricing and governance functions derived from and complementing the primary functions mentioned above. Fundamental prices of the economy, like exchange rates, interest rates, and risk premiums, are determined within the financial system. They guide the allocation of resources within and across organizations, industries, and national economies as well as across time. The final outcome of most financial transactions and the value of financial assets are exposed to risks, which need to be assessed and managed. This is necessarily the responsibility of those involved in financial transactions and in the creation of financial assets. Neglecting such responsibilities, can have severe consequences. The global financial crisis of 2008 originated from US housing market loans. Their default risk had been wrongly assessed by banks and rating agencies (Kirkpatrick, 2009). This negligence was caused by fundamental governance problems, namely, wrong incentives and lack of effective oversight.

All financial systems require four sets of resources. First, physical infrastructures are needed to support the circulation of money and information. Besides the secure transportation of cash and the network of branches and ATMs, modern financial systems rely heavily on telecommunication networks. Second, for the system to work, it is necessary that service providers, legislators, and regulators, and to some extent, corporate and individual users, all have sufficient financial knowledge. Third, given the informational nature of finance (see below), the functioning of a financial system requires trust. Trust is necessary because the value of information does not depend only on its content, but also on its reliability. Trust exists when participants mutually share consistent beliefs. These beliefs are genuinely linked to the knowledge base, the second resource mentioned above. Fourth, financial systems depend on a legal framework and regulatory oversight, i.e., rules as well as the institutions and procedures to implement them. This is not limited to the regulation of financial instruments, institutions, and markets, but also includes corporate law and bankruptcy legislation (see Kinoshita in this volume). By defining rights and duties, the legal framework supports not only the governance of the system, it also contributes to its overall stability and at least partially codifies its knowledge base. Taken together, the legal framework and regulatory oversight constitute an important source of trust. 
Design refers to the markets, organizations, financial instruments, business models, and products and services, which perform the actual functions of the financial system. The history of finance and the study of present-day financial systems clearly shows that there are various ways in which the respective functions can be performed (Neal et al. 2016; Kuroda, 2020). For example, the nature of money has changed in the course of history as have exchange rate regimes. Although modern economies now rely on fiat money created by central banks and commercial banks, the design of central and commercial banking has retained distinct national characteristics. The same applies to the role and importance of financial intermediation, financial regulation, public finance, corporate finance or the allocation of financial assets owned by private households.

On the surface, it may seem that national differences are the outcome of discrete and explicit design choices made by legislators, regulators, expert commissions, or business leaders in the financial industry. Respective choices are of course made, and they are especially needed when systems fail as in a crisis, or when, as in the case of DX, new technologies offer new resource and design options. However, the decisions are path-dependent. The choices are embedded in and constrained by the particular conditions of national contexts and by constellations of political and economic interests derived from the status quo.

\section{Japan and the Euro Zone}

As the contributions in this volume refer to Japan and the euro zone, it is necessary to provide some background information about Japan and the member states of the European Monetary Union. However, whereas Japan is a single nation-state, the euro zone is a very heterogeneous subgroup of 19 countries within the European Union (EU). This heterogeneity, which manifests itself in the data presented below, is actually a first and quite important feature of the monetary union. The unification under one currency system, the euro, established in 1999 with one central monetary authority-the European Central Bank (ECB). Various common regulations, oversight schemes, and stability mechanisms have been introduced over time. For instance, with the implementation of the Single Supervisory Mechanism (SSM) in 2014, a legislative and institutional framework for bank supervision, the ECB greatly expanded its responsibilities. Nevertheless, member states continue to differ widely not only in terms of size, economic activity, and economic structure, but also with regard to national regulations and policies. It is in fact one of the greatest challenges of the euro zone's central authorities and decision-making bodies to come up with common policies that are not only effective, but also do justice to the conditions of the different national contexts. 
Table 1 Basic economy characteristics of the eurozone and Japan (2020)

\begin{tabular}{l|l|l|l|l|l}
\hline & $\begin{array}{l}\text { Population in } \\
\text { millions }\end{array}$ & $\begin{array}{l}\text { GDP in } \\
\text { trillions US\$ }\end{array}$ & $\begin{array}{l}\text { Share of world } \\
\text { GDP* }\end{array}$ & $\begin{array}{l}\text { GDP per } \\
\text { capita** }\end{array}$ & $\begin{array}{l}\text { Share of } \\
\text { population } \\
\text { aged } \geq 65\end{array}$ \\
\hline Eurozone & 342.9 & 12.93 & $15.3 \%$ & 38,774 & $20 \%$ \\
\hline Max & 83.2 & 3.81 & $4.5 \%$ & 115,874 & $23 \%$ \\
\hline Median & 5.5 & 0.23 & $0.3 \%$ & 27,885 & $21 \%$ \\
\hline Min & 0.5 & 0.01 & $<0.01 \%$ & 17,620 & $14 \%$ \\
\hline Japan*** & 125.7 & 5.06 & $6.0 \%$ & 40,113 & $28 \%$ \\
\hline
\end{tabular}

Notes * Based on purchasing power parity, ** in current US\$, *** GDP data from 2019

Source OECD, Statistical Bureau of Japan, World Bank

\subsection{Basic Economic Data}

Table 1 shows basic economic data for the euro zone and Japan. The 19 economies comprising the euro zone produce more than $15 \%$ of world GDP, which corresponds to three times the volume of Japan's. It is noteworthy that the different countries of the euro zone are very diverse in terms of economic size, GDP per capita, and demographics. The euro zone economies' GDP per capita is on average not much different from Japan's. Japan and the euro zone are both facing demographic challenges due to their ageing populations. It is essential for these economies that they exploit the productivity potential inherent in DX in order to maintain their level of income.

\subsection{Financial Systems}

Given the many functions and design options, comparisons of financial systems confront various challenges. Although only superficial, a first impression can be gained by looking at national accounts statistics of the Organisation for Economic Co-operation and Development (OECD). ${ }^{2}$ Ignoring the outliers Mexico and Luxembourg, the financial sector accounts for between 1.5 and $5.3 \%$ of employment. With the exception of the UK, labor productivity is significantly higher in finance than in the rest of the economy. Again, excluding Luxembourg, which as a small economy operates an international financial hub, the data show a clear negative relationship between the employment share and the labor productivity of the sector relative to the rest of the economy. A simple conjecture would be that financial sectors expand because non-financial companies tend to outsource labor-intensive financial services.

The OECD financial dashboard, also based on national accounts statistics, provides additional information about structural characteristics (Table 2). It again

\footnotetext{
${ }^{2}$ Annual national accounts, detailed tables (stats.oecd.org.).
} 
Table 2 Characteristics of national financial systems (2018)

\begin{tabular}{|c|c|c|c|c|c|c|}
\hline & \multirow[t]{2}{*}{ Japan } & \multicolumn{3}{|c|}{ Euro zone } & \multirow[t]{2}{*}{ UK } & \multirow[t]{2}{*}{ US } \\
\hline & & Max & Median & Min & & \\
\hline $\begin{array}{l}\text { Household financial assets } \\
\text { in \% of national disposable } \\
\text { income }\end{array}$ & 596 & 712 & 319 & 159 & 481 & 548 \\
\hline $\begin{array}{l}\text { of which (\%): Cash and } \\
\text { deposits }\end{array}$ & 54 & 64 & 39 & 17 & 26 & 13 \\
\hline $\begin{array}{l}\text { Life insurance and } \\
\text { pensions }\end{array}$ & 25 & 65 & 17 & 4 & 54 & 33 \\
\hline $\begin{array}{l}\text { Equity and investment } \\
\text { funds }\end{array}$ & 14 & 71 & 31 & 10 & 16 & 45 \\
\hline $\begin{array}{l}\text { Gross debt of general } \\
\text { government in \% of GDP }\end{array}$ & 235 & 199 & 74 & 13 & 116 & 105 \\
\hline $\begin{array}{l}\text { Debt-to-equity ratio of } \\
\text { non-financial corporations }\end{array}$ & 0.9 & 1.5 & 1.0 & 0.6 & 0.8 & 0.7 \\
\hline $\begin{array}{l}\text { Financial intermediation } \\
\text { ratio }\end{array}$ & 0.5 & 0.7 & 0.5 & 0.4 & 0.7 & 0.5 \\
\hline
\end{tabular}

Source OECD, national accounts, financial dashboard, financial indicators (stock), stats.oecd.org

shows the wide variety across the euro zone with regard to the relative size of households' financial assets, their allocation across different asset classes, the structure of corporate finance, and the importance of financial intermediation. As for Japan, the most distinct features are the relative size of households' financial assets, almost double the euro zone average, the highly conservative allocation of these assets, and a record high level of government debt, which at least indirectly represents a liability for private households.

The most comprehensive framework for the analysis of financial systems has been developed by the World Bank and the International Monetary Fund (IMF) in response to the Asian Financial Crisis (World Bank and IMF, 2005). This framework aims at assessing the stability of national financial systems and policies. The various country reports, however, apply different statistical frameworks, which again reflects the fact that a standard framework cannot accommodate the wide diversity among national systems. The last euro zone report points to "the fragmented national legal frameworks for bank supervision" as a major area of reform (IMF, 2018, 8). It asserts that banks continue to play a dominant role within the system while financial markets have grown in importance (IMF, 2018, 9). The Japan country report emphasizes demographic change in combination with a low interest rate environment and low profitability as "posing chronic challenges for the financial system" (IMF, 2017, 6). Japan is, however, still seen to have "one of the largest and most sophisticated financial systems in the world," where banks continue to play a dominant role in financial intermediation (IMF, 2017, 9).

The report does not mention the profound changes the Japanese financial system underwent over the last 30 years. The balance sheet recession created by the burst 
of the stock price and real estate bubble at the beginning of the 1990s culminated in a domestic financial crisis at the end of the decade, which resulted in the failure of financial institutions and caused a wave of mergers among the largest commercial banks. ${ }^{3}$ Since the early 1990s, government debt has continuously risen. In 2020 , the gross debt-to-GDP ratio surpassed 250\% (Ministry of Finance, 2020), by far the highest among all OECD countries. Already in 1999, the Bank of Japan hit the zero lower bound and started putting the following unconventional monetary policies into action. ${ }^{4}$ Especially after the current Governor Haruhiko Kuroda assumed his position, the Bank of Japan (BOJ) embarked on a heavy monetary expansion in order to fight deflationary pressures. ${ }^{5}$ Parallel to the outstanding public debt, the monetary base has today reached a historically high level of 650 trillion yen at the end of June 2021, well surpassing Japan's annual GDP. ${ }^{6}$ Since the mid-1990s, Japan's non-financial corporate sector has become the country's largest provider of savings, thereby depressing the demand for loans. This gave commercial banks little choice, but to deposit the extra liquidity granted to them through monetary expansion in accounts held with the central bank (Waldenberger, 2017).

\subsection{Digitalization}

Japan and the euro zone are not in the driver's seat when it comes to DX. The International Institute for Management Development (IMD) World Digital Competitiveness Index 2020 assigns Japan rank 27 among 63 countries (IMD, 2020). Euro zone economies are positioned between rank 7 (the Netherlands) and 50 (Slovak Republic). The larger economies of Germany, France, Spain, and Italy are ranked at $18,24,33$, and 42 respectively, with an average rank for all 19 euro zone countries of 29. It is also interesting to note that Japan and many euro zone countries lost ground over the last five years. Their rankings declined, which means that they were unable to keep up with the worldwide development of digital services and technologies.

Statistics from the OECD Digital Economy Outlook 2020 draw a more diverse picture (OECD, 2020). Here, Japan scores relatively high with regard to business R\&D dedicated to the information industry, ICT patents, enterprise broadband connections, and mobile broadband connections. Germany, the largest euro zone economy, appears in the top ten ranks only with regard to fixed broadband subscriptions. The performance of the euro zone economies is again very diverse, ranging from the upper to the lower ranks.

\footnotetext{
${ }^{3}$ For instance, Yamaichi Securities, at the time Japan's fourth-largest securities company, and Hokkaido Takushoku Bank.

${ }^{4}$ The zero lower bound means that the implementation of negative nominal interest rates on deposits are constrained by the fact that economic agents can always hold cash. To cope with this constraint, the BOJ introduced the Quantitative Easing Policy (QEP) in 2001.

${ }^{5}$ For a detailed discussion of the BOJ's monetary policy, see Heckel and Nishimura (2022).

${ }^{6}$ https://www.boj.or.jp/en/statistics/boj/other/mb/base2106.pdf.
} 
The above statistics are not in line with the ambitions that Japan, Germany, and the European Union pursue in the area of digitalization. In 2016, the Japanese government came up with a comprehensive and highly ambitious vision, Society 5.0, explaining how the country would embrace the digital revolution (Waldenberger, 2018). Even earlier, Germany had started promoting the concept of the fourth industrial revolution, Industry 4.0, as the countries plan to take a lead in exploiting the productivity potential of DX for industry (Platform Industrie 4.0, 2019). In 2020, the European Union published "A European strategy for data", stating that "The EU can become a leading role model for a society empowered by data to make better decisions - in business and the public sector" (European Commission, 2020, p. 1, italics in the original). While many EU member states lag behind in digitalization, the EU certainly has taken a lead in the regulation of data protection and privacy by, for example, introducing the General Data Protection Regulation (GDPR). The EU competition authorities have also been most active in trying to prevent the leading, mainly US-based international platform companies, from abusing their dominant market positions and in pushing them to implement stricter transparency and data protection policies.

\section{DX and Finance: An Extended Overview}

\subsection{The Informational Nature of Finance}

Digital transformation represents a technological revolution, which permeates all aspects of our lives. It has been driven by tremendous increases in connectivity made possible by the internet, mobile networks, sensor technology, social networks, and platform business models, as well as by equally impressive advances in computing power as recently exemplified by neural networks and deep learning algorithms. However, the fundamental and seemingly unbound impact of DX is not just the outcome of technological progress. It is above all related to two other main factors. First, DX exploits two key characteristics of digitalized information, namely, that it can be limitlessly shared, i.e., copied, at almost zero marginal cost, and that it can be ubiquitous, i.e., its accessibility and use are not bound to a specific location. Second, receiving, analyzing, and sending information forms the basis of biological, social, and cultural life. DX is not making information an essential part of our existence. This has in fact always been the case. DX is making us aware of the existential nature of information and it offers us new tools to collect, analyze, and exchange vast amounts of information in previously unimaginable ways. How we use these new powers is a fundamentally important question. It will be addressed in this volume with a focus on a vital part of our economies, the financial system.

DX is radically transforming the financial industry. This is not surprising because finance is after all about collecting and processing information, an activity directly affected by DX. Money, the core element on which finance is built, is an ingenious 
information device. As a denominator of the price system and unit of accounting, it informs about the value of goods and services as well as assets and liabilities in balance sheets. As a storage of value and a means of exchange, it keeps a record of who has claims on the economy in terms of purchasing power and how these claims are reallocated when money changes hands in the process of trading, lending, and borrowing as well as saving and investing. Of course, the financial industry not only handles money. It also provides various services related to risk management and governance. But these again are activities that mainly consist of collecting and processing information.

It is not the first time that its informational nature made finance a front runner during fundamental economic transformations. The financial industry was among the first to be impacted by information and communication technologies (ICTs) (BátizLazo, 2015). Cashless transfers between banking accounts, the deployment of ATMs, and the use of credit and debit cards took early advantage of mainframe computers and telecommunication networks. Globalization, too, was a trend where the financial industry outpaced other sectors of the economy, when capital liberalization undid restrictions on cross-border financial transactions. Information, the basic input of financial activity, is not confined to a special location as in the case of a physical product. As a consequence, finance became a driver of globalization.

The impact of DX on the financial system is profound and broad, but it is also complex because the speed, extent, and details of the actual outcomes depend on national contexts. The following sections summarize the individual contributions and put them in context. As the chapters are not explicitly written in a comparative perspective, and as not all topics are covered with regard to both economies, we provide additional information. In doing so, we use the framework outlined above which describes the financial system in terms of functions, resources, and design. Applying this framework, it is important to note that DX does not change the primary and secondary functions of finance, as these do not depend on a specific technological regime. DX, however, impacts the resources and designs used to perform the functions. Many discussions of DX directly jump to the design level and pay little attention to the resource implications. We first look at the latter. As pointed out above, resources comprise physical infrastructures, knowledge, trust, and regulation.

\subsection{Infrastructures}

Central banks worldwide are today experimenting with digital currencies based on distributed ledger technologies (DLTs). DLTs exploit the immense increases in connectivity, computing power, and storage capacity. A recent survey by the Bank for International Settlements (BIS) shows that about $60 \%$ of central banks worldwide report that they are running experiments with central bank digital currencies (CBDCs) 
(Boar \& Wehrli, 2021: 7). ${ }^{7}$ For instance, the European Central Bank decided in July 2021 to start the investigation phase for a digital euro. ${ }^{8}$ If such new currency systems are to be introduced, they will make the existing infrastructures used for the circulation of cash and the transfer of money from bank accounts at least partly obsolete. Three contributions in this volume elaborate on design options for CBDCs. They are discussed below.

Crypto assets also make use of a DLT-based infrastructure. They were introduced in the private sector outside the public payment system (see the contribution by Bechtel et al.). Crypto assets and their infrastructures can be used for transactions and as a store of value. However, despite their impressive diffusion and valuation, they are not recognized as legal tender. Their use is limited to economic entities who explicitly agreed to participate by investing money or real assets in the respective schemes. The infrastructural implications of crypto assets depend on how far they are able to take over or support core functions of the financial system. The answer to this question remains unclear as there are still fundamental problems stemming not only from the high price volatility, but also from regulatory and security issues (see below).

Cashless mobile or online payments were made possible by the internet, mobile networks, smartphones, and the development and diffusion of application programming interfaces (APIs) (see contributions by Okina and Omarini). In contrast to DLTs, they rely on the existing banking infrastructure. Although they have important implications for the design level of business models, from an infrastructural perspective, they simply add what is essentially an additional digital layer.

\subsection{Knowledge Base}

DX affects the knowledge base of the financial system in myriad ways. The technology underlying DX itself represents new knowledge. Omarini highlights in her chapter how the European banking industry is struggling to adapt to DX. As value chains and business models are being transformed and consumers expect new service propositions, commercial banks have to basically reinvent themselves in order to stay competitive. Her analysis exemplifies the disruptive impact of DX on the knowledge base of commercial banking. The scarcity of adequately skilled human resources is often the decisive bottleneck in the adaptation and diffusion of new technology. DX is no exception. IT, computer, and system engineers are in high demand in the financial sector (PwC, 2019). Customers, both corporate and private, will also have to acquire new skills in order to benefit from new products and services, and to avoid

\footnotetext{
${ }^{7}$ Central banks and the Bank for International Settlements define CBDC as "a digital payment instrument, denominated in the national unit of account, that is a direct liability of the central bank" (Bank of Canada et al. 2020: 3).

${ }^{8}$ https://www.ecb.europa.eu/press/pr/date/2021/html/ecb.pr210714 d99198ea23.en.html.
} 
and control related risks (see next Subsection). Sasaki emphasizes in his chapter that customer education is also needed from a regulatory perspective.

Legislators and regulators, too, have to learn about the opportunities and risks of DX, lest they become unable to provide the frameworks needed for an efficient, stable, and safe transformation of the financial system. Around the world, universities, public and private research institutes, and think tanks have set up digital finance as a field of expertise. Governments, central banks, and regulatory agencies have installed internal research units together with study groups and external advisory bodies to gain expertise. They commission reports, experiment with regulatory sandboxes, and establish fintech-hubs to collect and exchange information and to showcase innovations (Financial Services Agency, 2021; Parenti, 2020). Typical for EU policymaking processes, the EU's digital finance strategy (European Commission, 2020) was based on broad public consultations. In addition, knowledge has been acquired through a series of public events under the Digital Finance Outreach. ${ }^{9}$ The Japanese government has a long tradition of using commissions of experts from academia and industry in its policymaking process (Neary, 2019). There are also numerous international forms of collaboration among policymakers and regulators within and outside established international organizations such as the IMF, the OECD, or BIS. One example is the joint distributed ledger technology project between the Bank of Japan and the European Central Bank referred to as Stella. ${ }^{10}$

Sasaki states in the very beginning of his chapter how regulators not only in Japan are having a hard time keeping up with new technological developments. He especially mentions the lack of human resources and emphasizes that regulators must collaborate closely with the private sector in order to cope with the speed of innovation. As Kinoshita points out, the Japanese financial system requires rules to be specified in great detail, because violations may be linked to criminal charges. This puts especially high demands on the expertise of Japanese legislators to adjust the legal framework in order to accommodate financial innovations because the more detailed rules afford more knowledge in the rule-making process.

Yamaoka's argument of a "private-led and two-layered" digital currency for Japan and Bechtel et al. roadmap show how private sector expertise and initiative can help to promote a digital payment infrastructure. The Study Group on Digital Settlement Infrastructure, which Yamaoka chaired, consisted of members from Japan's three mega-banking groups and leading non-financial companies. Representatives from respective ministries, the Bank of Japan, and the Financial Services Agency participated as observers. The Study Group soon reorganized as the Digital Currency Forum with more private corporations joining the initiative. Promoting system transformation through cross-industry consortia might be seen as a typical approach for a consensus-oriented society such as Japan. The process of knowledge sharing aims to ensure that the introduction of new payment infrastructures can benefit from a broad base of support.

\footnotetext{
${ }^{9} \mathrm{https} / / /$ ec.europa.eu/info/publications/digital-finance-outreach_en.

${ }^{10} \mathrm{https} / / /$ www.ecb.europa.eu/paym/intro/publications/pdf/ecb.miptopical200212.en.pdf.
} 
Not all knowledge underlying and affected by DX is publicly accessible. A typical field where knowledge is strictly proprietary is algorithmic trading, which highfrequency trading (HFT) depends on. Algorithmic trading is a black box to market participants who use its respective services, but also to regulators who are supposed to monitor its impact. The big question is, how can we trust it if we do not know how it works. One way is to look at performance. Kiuchi, who analyzes the role and relevance of algorithmic trading in Japan in this volume, concedes that recent research has shown HFT to enhance efficiency. What is less clear is how algorithms affect market stability in times of crises, which be definition are uncommon or outlier events for which computer programs are less likely to provide routines. Another aspect is fairness. Efficiency does not assure that everybody gets a fair share of the efficiency gains. Kiuchi stresses that Japanese regulators will need more knowledge and resources to detect unfair trading practices. He concludes that more research is needed to learn how HFT affects the income position of different market participants.

\subsection{Trust}

Trust is another essential resource impacted by DX. In fact, trust is already needed in the transition process to obtain the support of essential stakeholders. Bindseil's policy proposal for a "two-tier remuneration approach to CBDC" explicitly addresses concerns raised by private households and commercial banks who fear that CBDC could harm their interests. The same applies to other forms of new payment systems (see Okina).

In general, all the financial innovations made possible by DX are bound to affect trust as they come with new risks. Such risks concern the technical stability of new solutions, mistakes made by using new and therefore unfamiliar services, privacy, and security concerns related to the data requirements of digital financial services, and the protection against criminal or otherwise intentionally harmful actions by those trying to take advantage of the inexperience of users and legal loopholes. Not coping with these risks in an adequate way will undermine trust in and acceptance of digital financial innovations.

Promoters of DLTs argue that the underlying infrastructure inherently provides trust. Transaction-relevant information is documented in a transparent way, and manipulations are precluded because to try to attempt them would incur unreasonably high costs (Tapscott \& Tapscott, 2016). However, DLTs do bear severe security risks as incidents have shown.

Japan became one of the central turntables for blockchain in Asia and acted quite fast in introducing Crypto Assets. But Japan was also the country to experience the first large-scale security scandal. In 2014, Mt Gox, a Tokyo-based cryptocurrency exchange which once handled $80 \%$ of global bitcoin transactions, reported that 850,000 bitcoins worth $\$ 450$ million had been stolen. Mt Gox became insolvent (Leising, 2021). Four years later, a similar incident happened at yet another Japanese exchange, Coincheck, where hackers were able to steal digital tokens worth 
circa \$500 million (Bloomberg, 2018). The incidents show that crypto assets face severe security issues. To regain trust, Japan established the Japan Virtual Currency Exchange Association (JVCEA) in 2018, a self-regulatory organization, which has the authority to pass and implement rules and regulations for crypto assets.

Even if security issues are dealt with, the trust produced by decentralized consensus-building mechanisms used to certify transactions in DLT can be very expensive. As the blockchains within DLT applications grow, operating costs in terms of electricity consumption and time will increase. At some stage, it will be cheaper to establish a central authority entrusted with governance functions, but then the system would no longer be able to produce trust on its own.

\subsection{Legislation and Regulatory Oversight}

Legislation and regulatory oversight support trust by codifying knowledge relevant for market participants and by regulating and sanctioning actions in order to assure that the system is stable and performs in an efficient, secure, and fair manner. In doing so, legislators and regulators have to not only avoid unnecessary administrative burdens, but to also make sure that innovative activity is not unduly restricted. Sasaki discusses how the Japanese Financial Services Agency (FSA) has been trying to balance the protection of users and the promotion of innovation in its regulatory approaches to digital finance.

In adjusting to new technological regimes, legislators are constrained by existing legal and judicative systems. As already mentioned above, Japan's Financial Instruments and Exchange Act (FIEA), which forms the core of Japan's financial legislation, allows for the prosecution of violations under criminal law. According to Kinoshita, this retards legislative responses to financial innovation because lawmakers must specify rules, that provide the detail and clarity required by criminal law. He fears that Japan's financial industry will be left behind, if Japan does not fundamentally reform its approach to financial regulation.

The EU has played a central role in the promotion of DX in financial services. Omarini argues that regulation has been one of the major driving forces in the digital transformation of the European banking industry. The European Payment Service Directive 2 provided essential momentum for the industry in moving towards an open finance framework. The directive stimulated the entry by new companies and promoted cooperation between fintech companies and banks.

\subsection{Impact on Design}

For the general public, the most visible impact of DX is at the design level. This encompasses new forms of money, new ways of making payments, obtaining credit, saving, investing, and insuring as well as the new advisory services helping us to 
choose between different offers. Design aspects dominate the non-regulation chapters in the volume. Three of the contributions look at designs for central bank digital currencies.

Yamaoka provides an overview of currently used and discussed digital payment systems ranging from crypto assets, mobile payment services by banks, and nonfinancial companies based on the existing payment infrastructure, private digital currency initiatives such as Libra by Facebook and CBDCs. Based on his engagement with the Digital Currency Forum, he proposes a two-layered digital currency system for Japan. It would be issued by private-sector entities. Its upper layer would be equipped with customized programs including smart contracts to enhance the efficiency of payments and facilitate value-added transactions such as deliveryversus-payment (DvP), while its lower layer with common structure would enhance interoperability among various digital currency platforms.

Bindseil analyzes the design of CBDC under the aspect of remuneration, i.e., the rate of interest on CBDC deposits. Given recent interest rate policies by the $\mathrm{ECB}$, he specifically considers the introduction of CBDCs in an environment with negative interest rates. He proposes a two-tier remuneration system in which interest rates on CBDC deposits up to a certain threshold held by private households would be non-negative as in the case of cash, whereas CBDC holdings of corporates and larger holdings of households (beyond the threshold) could be charged a negative rate of interest if required for monetary policy or financial stability reasons. His design proposal explicitly aims to preserve the intermediary function of banks. Moreover, he clarifies that as central banks commit to continue supplying banknotes, introducing CBDC is not an instrument to "tax" households' money holdings through more negative interest rates.

Bechtel et al. provide a detailed discussion of the design options for DLTbased currency and payment infrastructures by comparing account- and token-based payment solutions, including, e-money tokens, synthetic central bank digital currencies, and CBDCs. They then outline a roadmap towards the introduction of central bank digital currencies for the euro zone. Bechtel et al. emphasize that the introduction of digital payment solutions based on DLTs is essential for achieving the EU's strategic goals of digital autonomy and competitiveness. The authors specifically present a three-pillar framework of a digital payments value chain consisting of (1) a contract execution system, (2) a digital payment infrastructure, and (3) a monetary unit. Similar to Yamaoka, they consider both the public and the private sector as potential issuers of a digital euro. However, they conclude that a single payment solution will not be able to meet the diverse demands by the private sector. Instead, a range of complementary account- and token-based payment systems are likely to emerge and co-exist in the foreseeable future.

Many innovations in the field of digital finance originate from fintech startups which, as their name indicates, apply the new technology to create new financial products and services. Fintech solutions allow cost savings and improved customer convenience through virtualization, automation, and seamless integration of processes, the personalization of products and services and the improved analytics made possible by big data and the use of "intelligent" algorithms. The 2nd Global Fintech Ranking 
Report (Findexable, 2021) documents the astonishing growth of the fintech industry. The report counted 108 fintech unicorns, i.e., non-listed startups with a market valuation of at least one billion US dollars in April 2021, up 61 cases from one year earlier. In terms of market valuation, fintech unicorns now account for $20 \%$ of all technology unicorns. Although fintech is a global phenomenon, the speed and scope of financial innovations differ markedly across countries. The report, which covers 11,000 companies in 264 cities and 83 countries, reflects these differences in its country and city rankings. The rankings are based on the number of privately owned fintech companies headquartered in a specific city or country, including supporting institutions, their performance, and the local or national business and regulatory environment. The country rankings see Japan at position 21, far behind the two Asian top runners, Singapore (4) and China (6). Seven euro zone countries are among the top 20, including the two larger economies of Germany (9) and Spain (16), ten are found among the next 30, whereas Greece and Slovakia occupy ranks 58 and 60 respectively, again showing the wide disparity among euro zone economies.

As Omarini explains in her chapter on commercial banking, whereas some, mainly highly internationalized fintechs, are able to operate independently, others cooperate with incumbent players because they are too small to make a full-fledged entry into finance. Incumbents in return profit from the innovative capacity of such partners. The cooperation between banks and fintechs is again supported by digital innovations such as APIs and promoted by new financial legislation. Large technology companies, Big Techs, have also entered the financial industry. By adding financial services to their platform business, they are able to further expand their capacity of collecting data. They are large enough to found their own financial group companies. As such, they pursue competitive rather than collaborative strategies.

Okina's empirical investigation reminds us that social traditions and customer preferences impact the design and diffusion of new technologies. Whereas Japan seems to be lacking behind with regard to cashless payments, the country has a highly developed loyalty points system, which has partly taken over functions of a cashless payment system. Not only the government and the FSA, but also Japanese e-commerce platforms such as Rakuten and the SoftBank (Yahoo!) Group have promoted payments using loyalty points. Loyalty points can today also be used to invest in exchange traded funds (ETFs) and real estate investment trusts (REIT) (Yomiuri Shinbun, 2021). The role that the loyalty points system will play in Japan's future payment system remains to be seen.

Kiuchi's account of algorithmic trading shows that HFT in equity markets is not yet as dominant in Japan as it is in the US. However, with US companies entering the Japanese market, HFT is already impacting the business models of Japan's security industry. 


\section{Concluding Remarks}

Looking at the momentum digital innovations in finance have been gaining worldwide over the last ten years, the amount of venture capital that new entrants into the industry have been able to raise and the support by national legislators and regulators, the DX of the financial system seems unstoppable. Nevertheless, at the level of individual economies, the DX of financial systems is diverse in terms of speed, scope, and outcome. National context matters.

Proponents of DX claim that a digitalized financial system can ameliorate the shortcomings of our present financial systems. Besides general efficiency gains, including improvements in convenience, they point to the possibility of eliminating surcharges on cross-border money transfers and to better social inclusion by providing financial products and services to people who have so far been denied bank accounts. But there are also numerous risks with regard to financial stability, privacy, and cyber security as well as fairness, which can hardly be overestimated. The key question then becomes how the transformation of the financial system can be governed to ensure that the opportunities outweigh the risks. This is closely related to the provision of one of the key resources discussed above, namely, knowledge. To benefit from financial innovation and to not fall victim to scams, the general public needs a sufficient level of financial literacy. But effective governance requires above all, that legislators and regulators have the knowledge necessary to safeguard the public interest. This is not a trivial problem because it will not suffice only to listen to advice provided by industry experts.

Effective governance needs an independent knowledge base, which is able to not only use expert knowledge provided by private industry, but to also assess to what extent advice from industry experts is useful in the pursuit of public policy goals (Waldenberger, 2019). Our publication is the outcome of such an endeavor. We hope it can contribute to the public discourse and further a critical understanding of the impact of DX on financial systems.

\section{References}

Bank of Canada, European Central Bank, Bank of Japan, Sveriges Riksbank, Swiss National Bank, Bank of England, Board of Governors Federal Reserve System, and Bank for International Settlements. (2020). Central bank digital currencies: Foundational principles and core features (Report No.1 in a series of collaborations from a group of central banks). Bank for International Settlements. https://www.bis.org/publ/othp33.pdf

Bátiz-Lazo, B. (2015). A brief history of the ATM: How automation changed retail banking, an object lesson. The Atlantic. https://www.theatlantic.com/technology/archive/2015/03/a-brief-his tory-of-the-atm $/ 388547 /$

Bloomberg. (2018). How to steal $\$ 500$ million in cryptocurrency. Fortune. https://fortune.com/ 2018/01/31/coincheck-hack-how/

Boar, C., \& Wehrli, A. (2021). Ready, steady, go? Results of the third BIS survey on central bank digital currency (BIS Papers No.114). Bank for International Settlements. 
Dore, R. (2000). Stock market capitalism: Welfare capitalism: Japan and Germany versus the Anglo-Saxons. Oxford University Press.

European Commission. (2020). Communication from the Commission to the European Parliament, the Council, the European economic and social committee and the committee of the regions on a European strategy for data (COM (2020) 66 final). https://eur-lex.europa.eu/legal-content/EN/ TXT/?uri=CELEX\%3A52020DC0066

Financial Services Agency. (2021). FinTech innovation hub katsudō hōkoku (dai 2 ban) [FinTech innovation hub: 2nd Activity Report].https://www.fsa.go.jp/policy/bgin/FIH_Report_2nd_ja.pdf

Findexable. (2021). Global Fintech rankings report: Bridging the gap. https://findexable.com/2021fintech-rankings/

Hall, P. A., \& Soskice, D. (2001). Varieties of capitalism: The institutional foundations of comparative advantage. Oxford University Press.

Heckel, M., \& Nishimura, K. G. (2022). Unconventional monetary policy through open market operations: A principal component analysis. Asian Economic Papers. Forthcoming.

Hines, B. (2021). Digital finance: Security tokens and unlocking the real potential of blockchain. Wiley.

International Institute for Management Development. (2020). IMD world digital competitiveness ranking 2020. IMD World Competitiveness Center. https://www.imd.org/centers/world-compet itiveness-center/rankings/world-digital-competitiveness/

International Monetary Fund. (2017). Japan: Financial system stability assessment (IMF Country Report No. 17/244). https://www.imf.org/en/Publications/CR/Issues/2017/07/31/Japan-Financ ial-System-Stability-Assessment-45151

International Monetary Fund. (2018). Euro area policies: Financial system stability assessment (IMF Country Report No. 18/226). https://www.imf.org/en/Publications/CR/Issues/2018/07/19/ Euro-Area-Policies-Financial-System-Stability-Assessment-46100

Kirkpatrick, G. (2009). The corporate governance lessons from the financial crisis. OECD Journal: Financial Market Trends, 2009(1), 61-87.

Kuroda, A. (2020).A global history of money. Routledge.

Leising, M. (2021, January 31). 'Trillion Dollar' Mt. Gox demise as told by a bitcoin insider. Bloomberg. https://www.bloomberg.com/news/articles/2021-01-31/-trillion-dollar-mt-gox-dem ise-as-told-by-a-bitcoin-insider

McMillan, J. (2014). The end of banking: Money, credit, and the digital revolution. Zero/One Economics.

Ministry of Finance. (2020). Japanese public finance fact sheet. https://www.mof.go.jp/english/pol icy/budget/budget/fy2020/04.pdf

Neal, L., Fohlin, C., Burhop, C., \& Chambers, D. (2016). Part 2: Stock markets. In D. Chambers, \& E. Dimson (Eds.), Financial market history: Reflections on the past for investors today. CFA Institute Research Foundation.

Neary, I. (2019). The state and politics in Japan. Polity Press.

Organisation for Economic Co-operation and Development. (2020). OECD Digital Economy Outlook 2020.

Parenti, R. (2020). Regulatory sandboxes and innovation hubs for FinTech: Impact on innovation, financial stability and supervisory convergence. European Parliament.

Platform Industrie 4.0. (2019). 2030 Vision for industry 4.0: Shaping digital ecosystems globally. BMWi.

PwC. (2019). Financial services talent trends 2019. https://www.pwc.com/gx/en/ceo-survey/2019/ Theme-assets/reports/financial-services-talent-ceo-survey-trends-report-2019.pdf

Tapscott, D., \& Tapscott, A. (2016). Blockchain revolution: How the technology behind bitcoin is changing money, business, and the world. Penguin Random House.

Waldenberger, F. (2017). Fully reserve-backed money: A solution to Japan's fiscal and monetary challenges. In: F. Rövekamp, M. Bälz, \& H. G. Hilpert (Eds.), Cash in East Asia (pp. 77-98). Springer. 
Waldenberger, F. (2018). Society 5.0. Japanese ambitions and initiatives. In: Konrad Adenauer Stiftung (Eds.), The digital future (= International Reports 1, 2018) (pp. 48-55).

Waldenberger, F. (2019). Einige Überlegungen zu den Möglichkeiten und Grenzen staatlicher Regulierung in einer durch Arbeitsteilung geprägten Wissensgesellschaft. In: T. Baums, H. Remsperger, M. Sachs und V.W. Wieland (Eds.), Zentralbanken, Währungsunion und stabiles Finanzsystem. Festschrift für Helmut Siekmann (pp. 621-635). Duncker and Humblot.

World Bank, The and International Monetary Fund. (2005). Financial sector assessment: A handbook. The International Bank for Reconstruction and Development/The World Bank/The International Monetary Fund.

Yomiuri Shinbun. (2021, July 14). Genkin tsukawazu kin'yü shōhin [Non-cash purchase of financial instruments]. Yomiuri Shinbun.

Open Access This chapter is licensed under the terms of the Creative Commons AttributionNonCommercial-NoDerivatives 4.0 International License (http://creativecommons.org/licenses/bync-nd/4.0/), which permits any noncommercial use, sharing, distribution and reproduction in any medium or format, as long as you give appropriate credit to the original author(s) and the source, provide a link to the Creative Commons license and indicate if you modified the licensed material. You do not have permission under this license to share adapted material derived from this chapter or parts of it.

The images or other third party material in this chapter are included in the chapter's Creative Commons license, unless indicated otherwise in a credit line to the material. If material is not included in the chapter's Creative Commons license and your intended use is not permitted by statutory regulation or exceeds the permitted use, you will need to obtain permission directly from the copyright holder.

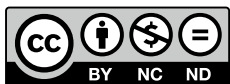

